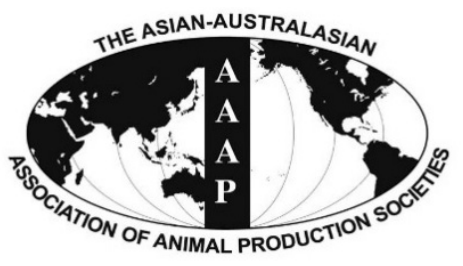

\title{
Influence of Feeding Enzymatically Hydrolyzed Yeast Cell Wall on Growth Performance and Digestive Function of Feedlot Cattle during Periods of Elevated Ambient Temperature
}

\author{
J. Salinas-Chavira*, C. Arzola ${ }^{1}$, V. González-Vizcarra², O. M. Manríquez-Núñez², M. F. Montaño-Gómez², \\ J. D. Navarrete-Reyes ${ }^{2}$, C. Raymundo ${ }^{2}$, and R. A. Zinn ${ }^{3}$ \\ Facultad de Medicina Veterinaria y Zootecnia, Universidad Autónoma de Tamaulipas, \\ Cd. Victoria, Tamaulipas 87000, México
}

\begin{abstract}
In experiment 1, eighty crossbred steers $(239 \pm 15 \mathrm{~kg})$ were used in a $229-\mathrm{d}$ experiment to evaluate the effects of increasing levels of enzymatically hydrolyzed yeast (EHY) cell wall in diets on growth performance feedlot cattle during periods of elevated ambient temperature. Treatments consisted of steam-flaked corn-based diets supplemented to provide $0,1,2$, or $3 \mathrm{~g} \mathrm{EHY/hd/d}$. There were no effects on growth performance during the initial 139-d period. However, from d 139 to harvest, when 24-h temperature humidity index averaged 80, EHY increased dry matter intake (DMI) (linear effect, $\mathrm{p}<0.01$ ) and average daily gain (ADG) (linear effect, $\mathrm{p}=0.01)$. There were no treatment effects $(\mathrm{p}>0.10)$ on carcass characteristics. In experiment 2 , four Holstein steers $(292 \pm 5 \mathrm{~kg})$ with cannulas in the rumen and proximal duodenum were used in a $4 \times 4$ Latin Square design experiment to evaluate treatments effects on characteristics of ruminal and total tract digestion in steers. There were no treatment effects $(\mathrm{p}>0.10)$ on ruminal $\mathrm{pH}$, total volatile fatty acid, molar proportions of acetate, butyrate, or estimated methane production. Supplemental EHY decreased ruminal molar proportion of acetate $(\mathrm{p}=0.08)$, increased molar proportion of propionate $(\mathrm{p}=0.09)$, and decreased acetate:propionate molar ratio $(\mathrm{p}=0.07)$ and estimated ruminal methane production $(\mathrm{p}=0.09)$. It is concluded that supplemental EHY may enhance DMI and ADG of feedlot steers during periods of high ambient temperature. Supplemental EHY may also enhance ruminal fiber digestion and decrease ruminal acetate:propionate molar ratios in feedlot steers fed steam-flaked corn-based finishing diets. (Key Words: Yeast, Growth Performance, Digestion, Cattle)
\end{abstract}

\section{INTRODUCTION}

Temperature-Humidity index (THI; Mader et al., 2006) greater than 74 is considered stressful for cattle. This condition is prevalent during much of the summer months throughout the desert southwestern United States of

\footnotetext{
* Corresponding Author: J. Salinas-Chavira. Tel: $+52-8343073$ 376, E-mail: jsalinasc@hotmail.com

${ }^{1}$ Facultad de Zootecnia, UACH, Chihuahua, Chihuahua 31000, México.

${ }^{2}$ Instituto de Investigaciones en Ciencias Veterinarias, UABC, Mexicali, Baja California 21100, México.

${ }^{3}$ Department of Animal Science, University of California, Davis 95616, USA.

Submitted Jan. 24, 2015; Revised Feb. 17, 2015; Accepted Mar. 20, 2015
}

America. This heat load causes a reduction in energy intake (Young and Hall, 1993; Hahn, 1994) and hence, average daily gain (ADG) and gain efficiency (Blackshaw and Blackshaw, 1994; Hubbard et al., 1999). Additionally, heat stress alters endocrine profiles and energy metabolism of cattle (Rhoads et al., 2009).

In dairy cattle, supplementation with yeast and/or yeast cell wall components has been associated with reduction of negative impact of heat stress on cattle that has improved milk yield, enhanced immune status, and reduced incidence of mastitis and somatic cell counts (Nocek et al., 2011; Liu et al., 2014). Likewise, supplementation improved health status and immune response, reducing physiological and acute phase responses of cattle exposed to endotoxin challenge (Lowry et al., 2005; Li et al., 2006; Chae et al., 
2006; Sanchez et al., 2013; 2014). With respect to digestion, supplementation may also enhance ruminal $\mathrm{pH}$ and ruminal fiber digestion (Beauchemin et al., 2003). There is very limited information regarding the effects of enzymatically hydrolyzed yeast (EHY) cell wall components on growth performance of feedlot cattle, particularly during period of high ambient temperature to which a majority of feedlot cattle will be exposed during some portion of the growingfinishing period. The objective of present research was to evaluate influence of supplementing EHY on growth performance and digestive function of feedlot cattle during periods of elevated ambient temperature.

\section{MATERIALS AND METHODS}

All procedures involving animal care and management were in accordance with and approved by the University of California, Davis, Animal Use and Care Committee.

Experiment 1, influence of enzymatically hydrolyzed yeast on growth performance, dietary energetics and carcass characteristics

Eighty crossbred steers (approximately 25\% Brahman with the remainder represented by Hereford, Angus, Shorthorn and Charolais breeds in various proportions) with an average weight of $239 \pm 15 \mathrm{~kg}$ were used in a $229-\mathrm{d}$ experiment to evaluate the effects of EHY cell wall (TruMax, Vi-COR, Mason City, IA, USA) supplementation on growth performance, dietary net energy, and carcass characteristics of feedlot cattle. Upon arrival, steers were vaccinated for bovine rhinotracheitis-parainfluenza (Cattle Master Gold FP 5 L5, Zoetis, New York, NY, USA), clostridials (Ultrabac-7, Zoetis, USA), treated for parasites (Dectomax Injectable, Zoetis, USA), injected subcutaneously with 500,000 IU vitamin A (Vital E-A + D3, Stuart Products, Bedford, TX, USA), and 1,200 mg ceftiofur (Excede, Zoetis, USA), branded, ear-tagged, and implanted with Revalor-IS (Intervet, Millsboro, DE, USA). Bull calves were castrated and horns, if present, were tipped. Steers were blocked by weight and randomly assigned within weight groupings to 16 pens (4 pens per treatment; 5 steers per pen). Pens were $43 \mathrm{~m}^{2}$ with $22 \mathrm{~m}^{2}$ of overhead shade, automatic waterers, and 2.4 fence-line feed bunks. Treatments consisted of steam-flaked corn-based diets supplemented to provide $0,1,2$, or $3 \mathrm{~g} \mathrm{EHY/hd/d}$. Ingredient and nutrient composition of diets are shown in Table 1. Diets were prepared at weekly intervals and stored in plywood boxes located in front of each pen. Steers were allowed ad libitum access to their experimental diets. Fresh feed was provided twice daily. Individual steers were weighed upon initiation and at periods of 28-d until completion of the 229-d trial. In the calculation of steer performance live weights were reduced $4 \%$ to adjust for digestive tract fill. Estimates of steer performance were based on pen means. Readings of daily ambient temperature and humidity during the course of the study were obtained from the California Department of Water Resources Information and Management System (CIMIS) weather station located roughly 100 meters distance from the feedlot.

Energy gain (EG) was calculated by the equation: $\mathrm{EG}=$ $\mathrm{ADG}^{1.097} 0.0557 \mathrm{~W}^{0.75}$, where $\mathrm{EG}$ is the daily-energydeposited (Mcal/d), W is the mean shrunk body weight (BW) $(\mathrm{kg}$; NRC, 1984). Maintenance energy (EM) was calculated by the equation: $\mathrm{EM}=0.077 \mathrm{~W}^{0.75}(\mathrm{NRC}, 1996)$. Dietary net energy of gain $(\mathrm{NEg})$ was derived from net energy of maintenance (NEm) by the equation: $\mathrm{NEg}=$ 0.877 NEm-0.41 (Zinn and Shen, 1998). Dry matter intake (DMI) is related to energy requirements and dietary NEm according to the equation: $\mathrm{DMI}=\mathrm{EM} / \mathrm{NEm}+\mathrm{EG} /(0.877$ NEm -0.41), and can be resolved for estimation of dietary NEm by means of the quadratic formula: $x=\left(-b \pm\left[b^{2}-\right.\right.$ $\left.4 \mathrm{ac}]^{0.5}\right) / 2 \mathrm{a}$, where $\mathrm{x}=\mathrm{NEm}, \mathrm{a}=-0.877 \mathrm{DMI}, \mathrm{b}=0.877$ $\mathrm{EM}+0.41 \mathrm{DMI}+\mathrm{EG}$, and $\mathrm{c}=-0.42 \mathrm{EM}$ (Zinn and Shen, 1998).

Hot carcass weights $(\mathrm{HCW})$ were obtained at time of slaughter. After carcasses chilled for $48 \mathrm{~h}$, the following measurements were obtained: LM area $\left(\mathrm{cm}^{2}\right)$ by direct grid reading of the Longissimus muscle (LM) at the 12th rib; subcutaneous fat $(\mathrm{cm})$ over the LM at the 12th rib taken at a location $3 / 4$ the lateral length from the chine bone end (adjusted by eye for unusual fat distribution); kidney, pelvic and heart fat $(\mathrm{KPH})$, as a percentage of $\mathrm{HCW}$; marbling score (USDA 1997; using 3.0 as minimum slight, 4.0 as minimum small, 5.0 as minimum modest, 6.0 as minimum moderate, etc.), and estimated retail yield of boneless, closely trimmed retail cuts from the round, loin, rib and chuck (\% of HCW; Murphey et al., 1960) = $52.56-$ $1.95 \times$ subcutaneous fat $-1.06 \times \mathrm{KPH}+0.106 \times \mathrm{LM}$ area $0.018 \times \mathrm{HCW}$.

For calculating steer performance, initial BW is the arrival off-truck shrunk weight. Interim and final LW was reduced $4 \%$ to account for digestive tract fill. Final shrunk LW was adjusted for HCW by dividing HCW by the decimal fraction of the average dressing percentage (0.64). Pens were used as experimental units. The experimental data were analyzed as a randomized complete block design experiment according to the following statistical model:

$$
Y_{i j}=\mu+B_{i}+T_{j}+E_{i j}
$$

Where $\mu$ is the common experimental effect, $B_{i}$ represents initial weight group effect $(\mathrm{df}=3), T_{j}$ represents dietary treatment effect $(\mathrm{df}=3)$, and $E_{i j}$ represents the residual error $(\mathrm{df}=9)$. Treatments effects were tested using the following contrasts: 0 vs EHY, and linear and quadratic polynomials (Stastix 9, Analytical Software, Tallahassee, 
FL, USA).

Experiment 2, influence of enzymatically hydrolyzed yeast on digestive function of steers

Four Holstein steers $(264 \pm 5 \mathrm{~kg})$ with cannulas in the rumen (3.8 $\mathrm{cm}$ internal diameter) and proximal duodenum (Zinn and Plascencia, 1993) were used in a $4 \times 4$ Latin square experiment to evaluate the influence of EHY (TruMax, Vi-COR, USA) supplementation-level in finishing diets for steers based on steam-flaked corn and distillers dried gains plus solubles on characteristics of rumen and total tract digestion. Dietary treatments were the same as indicated for the finishing diet used in Trial 1 (Table 1) plus the inclusion of chromic oxide $(2.5 \mathrm{~g} / \mathrm{kg})$ as a digesta marker. Steers were maintained in individual pens $\left(5.6 \mathrm{~m}^{2}\right)$ with automatic waterers. Diets were fed at 08:00 and 20:00 h daily. In order to avoid the complications of feed refusals, DMI was restricted to $6.02 \mathrm{~kg} / \mathrm{d}(2.3 \%$ of $\mathrm{BW})$. Experimental periods were $14 \mathrm{~d}$, with $10 \mathrm{~d}$ for dietary treatment adjustment, $4 \mathrm{~d}$ for collection. During collection, duodenal and fecal samples were taken twice daily as follows: day 1, 0750 and $1350 \mathrm{~h}$; day 2, 0900 and $1500 \mathrm{~h}$; day 3, 1050 and $1650 \mathrm{~h}$, and day 4, 1200 and $1800 \mathrm{~h}$. Individual samples consisted of approximately $700 \mathrm{~mL}$ of duodenal chyme and $200 \mathrm{~g}$ (wet basis) of fecal material. Samples from each steer within each collection period were composited for analysis. During the final day of each collection period, ruminal samples were obtained from each steer via ruminal cannula $4 \mathrm{~h}$ after feeding. Ruminal fluid $\mathrm{pH}$ was determined on fresh samples. Samples were strained through 4 layers of cheesecloth. Two milliliters of freshly prepared $(25 \mathrm{~g} / 100 \mathrm{~mL})$ meta-phosphoric acid was added to $8 \mathrm{~mL}$ of strained ruminal fluid. Samples were then centrifuged $(17,000 \times \mathrm{g}$ for $10 \mathrm{~min})$, and supernatant fluid was stored at $-20^{\circ} \mathrm{C}$ for volatile fatty acid (VFA) analysis (gas chromatography; Zinn, 1988). Upon completion of the experiment, ruminal fluid was obtained via the ruminal cannula from all steers and composited for isolation of

Table 1. Composition of experimental diets fed to steers ${ }^{1}$

\begin{tabular}{|c|c|c|c|c|}
\hline \multirow{2}{*}{ Item } & \multicolumn{4}{|c|}{ Diets (\%, DM basis) } \\
\hline & Receiving $^{2}$ & Transition $1^{3}$ & Transition $2^{4}$ & Finishing $^{5,6}$ \\
\hline Alfalfa, hay & 20.0 & 10 & 5.0 & 0.0 \\
\hline Sudangrass hay & 12.0 & 12.0 & 12.0 & 12.0 \\
\hline Steam-flaked corn & 36.31 & 45.63 & 52.24 & 57.73 \\
\hline Distillers dried gains + solubles & 20.0 & 20.0 & 20.0 & 20.0 \\
\hline Tallow & 2.0 & 2.0 & 2.0 & 2.3 \\
\hline Cane molasses & 8.0 & 8.0 & 6.0 & 5.0 \\
\hline Limestone & 0.73 & 1.2 & 1.49 & 1.6 \\
\hline Urea & 0.45 & 0.65 & 0.75 & 0.85 \\
\hline Magnesium oxide & 0.10 & 0.10 & 0.10 & 0.10 \\
\hline Trace mineral salt $^{7}$ & 0.40 & 0.40 & 0.40 & 0.40 \\
\hline Rumensin & 0.014 & 0.017 & 0.017 & 0.017 \\
\hline \multicolumn{5}{|l|}{ Nutrient composition (DM basis) $^{8}$} \\
\hline \multicolumn{5}{|l|}{$\mathrm{NE}(\mathrm{Mcal} / \mathrm{kg})$} \\
\hline Maintenance & 1.97 & 2.06 & 2.11 & 2.17 \\
\hline Gain & 1.33 & 1.40 & 1.15 & 1.51 \\
\hline Crude protein $(\mathrm{g} / \mathrm{kg})$ & 16.02 & 15.48 & 15.28 & 15.03 \\
\hline Ether extract $(\mathrm{g} / \mathrm{kg})$ & 6.4 & 6.51 & 6.65 & 7.04 \\
\hline Calcium $(\mathrm{g} / \mathrm{kg})$ & 0.80 & 0.80 & 0.80 & 0.75 \\
\hline Magnesium (\%) & 0.30 & 0.30 & 0.29 & 0.29 \\
\hline Phosphorus (g/kg) & 0.37 & 0.38 & 0.38 & 0.39 \\
\hline NDF & 28.79 & 25.43 & 23.92 & 22.32 \\
\hline
\end{tabular}

DM, dry matter; NE, net energy; NDF, neutral detergent fiber; EHY, enzymatically hydrolyzed yeast.

${ }^{1}$ Diets were supplemented to provide for an average estimated intake of $0,1,2$, or $3 \mathrm{~g} / \mathrm{hd} / \mathrm{d}$ of EHY (TruMax, Vi-COR, Mason City, IA, USA) during respective feeding periods.

${ }^{2}$ Receiving diet (fed from d 1 to d 28) supplemented with $0,171.8,343.5$, or $515.3 \mathrm{mg} / \mathrm{kg}$ EHY (DM basis).

${ }^{3}$ Transition 1 diet (fed from d 28 to d 35) supplemented with 0, 147.5, 295.0, or 201.1 mg/kg EHY (DM basis).

${ }^{4}$ Transition 2 diet (fed from d 35 to d 42) supplemented with 0, 138.5, 277.0, or $415.5 \mathrm{mg} / \mathrm{kg}$ EHY (DM basis).

${ }^{5}$ Finishing diet (fed from d 42 to d 229) supplemented with 0, 116.0, 232.0, or $348.0 \mathrm{mg} / \mathrm{kg}$ EHY (DM basis).

${ }^{6}$ Chromic oxide $(0.40 \%)$ was added as digesta marker in experiment 2.

${ }^{7}$ Trace mineral salt contained: $\mathrm{CoSO}_{4}, 0.068 \%$; $\mathrm{CuSO}_{4}, 1.04 \% ; \mathrm{FeSO}_{4}, 3.57 \% ; \mathrm{ZnO}, 0.75 \%$; $\mathrm{MnSO}$, $1.07 \% ; \mathrm{KI}, 0.052 \%$; $\mathrm{NaCl}, 93.4 \%$.

${ }^{8}$ Based on tabular values for individual feed ingredients (NRC, 1984) with exception of supplemental fat which was assigned $\mathrm{NE}_{\mathrm{m}}$ and $\mathrm{NE}_{\mathrm{g}}$ values of 6.03 and 4.79 Mcal $/ \mathrm{kg}$, respectively (Zinn, 1988). 
ruminal bacteria by differential centrifugation (Bergen et al., 1968).

Feed and fecal samples were subjected to the following analysis: DM (oven drying at $105^{\circ} \mathrm{C}$ until no further weight loss); ash (method 942.05, AOAC, 1986), Kjeldahl $\mathrm{N}$ (method 984.13, AOAC, 2000); aNDFom (Van Soest et al., 1991), corrected for neutral detergent fiber (NDF)-ash, incorporating heat stable $\alpha$-amylase (Ankom FAA, Ankom Technology, Macedon, NY, USA) at $1 \mathrm{~mL}$ per $100 \mathrm{~mL}$ of NDF solution); chromic oxide (Hill and Anderson, 1958); and starch (Zinn, 1990). Duodenal samples were subjected the following analysis: DM (oven drying at $105^{\circ} \mathrm{C}$ until no further weight loss); ash (method 942.05, AOAC, 1986), Kjeldahl N (method 984.13, AOAC, 2000), ammonia N (method 941.04, AOAC, 2000); aNDFom (Van Soest et al., 1991), corrected for NDF-ash, incorporating heat stable $\alpha$ amylase (Ankom FAA, Ankom Technology, USA) at $1 \mathrm{~mL}$ per $100 \mathrm{~mL}$ of NDF solution); purines (Zinn and Owens, 1986); chromic oxide (Hill and Anderson, 1958); and starch (Zinn, 1990). Duodenal flow and fecal excretion of DM were calculated based on marker ratio, using chromic oxide. Microbial organic matter (MOM) and $\mathrm{N}(\mathrm{MN})$ leaving the abomasum was calculated using purines as a microbial marker (Zinn and Owens, 1986). Organic matter (OM) fermented in the rumen was considered equal to OM intake minus the difference between the amount of total OM reaching the duodenum and MOM reaching the duodenum. Feed $\mathrm{N}$ escape to the small intestine was considered equal to total $\mathrm{N}$ leaving the abomasum minus ammonia- $\mathrm{N}, \mathrm{MN}$, and endogenous $\mathrm{N}\left(0.195 \times \mathrm{BW}^{0.75}\right.$, Ørskov et al., 1986). Methane production ( $\mathrm{mol} / \mathrm{mol}$ glucose equivalent fermented) was estimated based on the theoretical fermentation balance for observed molar distribution of VFA (Wolin, 1960).

The effects of EHY cell wall level $(0,1,2$, or $3 \mathrm{~g}$ $\mathrm{EHY} / \mathrm{hd} / \mathrm{d}$ ) on characteristics of digestion in cattle were analyzed as a balanced $4 \times 4$ Latin square design experiment:

$$
Y_{i j k}=\mu+S_{i}+P_{j}+T_{k}+E_{i j k},
$$

Where, $Y_{i j k}$ is the response variable, $\mu$ is the common experimental effect, $S_{i}$ is the steer effect, $P_{j}$ is the period effect, $T_{k}$ is the treatment effect and $E_{i j k}$ is the residual error. Treatment effects were tested using the following contrasts: 0 vs EHY, and linear and quadratic polynomials (Stastix 9, Analytical Software, USA).

\section{RESULTS AND DISCUSION}

Experiment 1, influence of enzymatically hydrolyzed yeast on growth performance, dietary energetics and carcass characteristics

Treatment effects on growth performance are shown in Table 2. There were no effects on growth performance during the initial 139-d period. However, from d-139 to harvest, when 24-h temperature humidity index averaged 80 , EHY increased DMI (linear effect, $\mathrm{p}<0.01$ ) and ADG (linear effect, $p=0.01$ ). This improvement in ADG was largely due to increased DMI, as gain efficiency and estimated dietary NE were not affected by EHY supplementation (Table 2). Comparable studies evaluating effects of EHY on feedlot cattle growth-performance are limited. In a 56-d feeding trial, Finck et al. (2010) observed increased ADG associated with increased DMI in feedlot steers fed a receiving diet supplemented to provide $5 \mathrm{~g} / \mathrm{d}$ yeast cell wall. In a 50-d feeding trial, Lei et al. (2013) observed increased ADG and gain efficiency in feedlot steers fed $2 \mathrm{~g}$ d of a yeast cell wall product.

Considering supplemental yeast, per se, Hinman et al. (1998) in a 115-d trial observed greater ADG and gain efficiency in feedlot steers supplemented with yeast. In contrast, Swyers et al. (2014) did not observed an effect of supplemental yeast on in a 125-d feedlot growth performance of yearling steers. Likewise, Baumann et al. (2004) observed no advantage of yeast supplementation on 126-d ADG and gain efficiency of growing-finishing feedlot steers.

Observed variation in growth-performance response to EHY supplementation as affected by periods of unfavorable ambient conditions, may be more particularly a function of immune status (Swyers et al., 2014). Heat stress alters endocrine profiles and energy metabolism in cattle (Rhoads et al., 2009). Supplemental EHY can modulate immune status (Nocek et al., 2011; Lei, et al., 2013; Sanchez et al., 2013; 2014). Sanchez et al. (2014) observed that in beef heifers newly-received into the feedlot, supplementation with yeast cell wall enhanced energy metabolism during an immune challenge. Ganner et al. (2010) observed that yeast derivatives (cell walls) had a selective effect against some pathogenic bacteria. Reisinger et al. (2012) observed that yeast cell wall supplementation increased jejunal goblet cell density, reducing the number of apoptotic enterocytes. Lei et al. (2013) observed that yeast cell wall can effectively bind lipopolysaccharides within the intestine, preventing translocation into the circulation.

Liu et al. (2014) observed that yeast supplementation improved milk yield and immune response of dairy cows under conditions of heat stress. Temperature-humidity index $(\mathrm{THI}=[0.8 \times$ ambient temperature $]+[\{\%$ of relative humidity $/ 100\} \times\{$ ambient temperature-14.4\}]+46.4), a measure of heat load, is coded as follows: normal, THI $<74$; alert, $75<\mathrm{THI}<78$; danger, $79<\mathrm{THI}<83$; and emergency, THI >84 (Mader et al., 2006). In the present study, enhancements in DMI and ADG during the period of high THI may indicate a potential role of EHY in association with heat stress.

Consistent with overall treatment effects on ADG and 
Table 2. Influence of enzymatically hydrolyzed yeast (EHY) supplementation on growth-performance of crossbred feedlot steers

\begin{tabular}{|c|c|c|c|c|c|c|c|c|}
\hline \multirow{2}{*}{ Item } & \multicolumn{4}{|c|}{ EHY (g/steer/d) } & \multirow{2}{*}{ SEM } & \multicolumn{3}{|c|}{$\mathrm{p}$-value } \\
\hline & 0 & 1 & 2 & 3 & & 0 vs EHY & Linear & Quadratic \\
\hline Pen replications & 5 & 5 & 5 & 5 & & & & \\
\hline \multicolumn{9}{|l|}{ Body weight $(\mathrm{kg})^{1}$} \\
\hline Initial & 235.0 & 233.9 & 235.0 & 234.5 & 0.3 & & & \\
\hline $139 \mathrm{~d}$ & 467.2 & 457.4 & 460.1 & 470.7 & 10.5 & 0.73 & 0.77 & 0.88 \\
\hline 229 d (Final) & 550.2 & 545.2 & 548.4 & 566.3 & 12.0 & 0.82 & 0.36 & 0.91 \\
\hline \multicolumn{9}{|l|}{$\operatorname{ADG}(\mathrm{kg} / \mathrm{d})$} \\
\hline 1 to $139 \mathrm{~d}$ & 1.67 & 1.61 & 1.63 & 1.70 & 0.07 & 0.76 & 0.77 & 0.94 \\
\hline 139 to $229 \mathrm{~d}$ & 0.92 & 0.98 & 0.97 & 1.06 & 0.03 & 0.04 & 0.01 & 0.29 \\
\hline 1 to $229 \mathrm{~d}$ & 1.38 & 1.36 & 1.37 & 1.45 & 0.05 & 0.80 & 0.35 & 0.86 \\
\hline \multicolumn{9}{|l|}{ DMI (kg/d) } \\
\hline 1 to $139 \mathrm{~d}$ & 7.75 & 7.69 & 7.49 & 7.72 & 0.17 & 0.58 & 0.73 & 0.49 \\
\hline 139 to $229 \mathrm{~d}$ & 8.00 & 7.98 & 8.38 & 8.40 & 0.10 & 0.07 & $<0.01$ & 0.12 \\
\hline 1 to $229 \mathrm{~d}$ & 7.85 & 7.80 & 7.84 & 7.99 & 0.14 & 0.88 & 0.49 & 0.96 \\
\hline \multicolumn{9}{|l|}{ ADG/DMI } \\
\hline 1 to $139 \mathrm{~d}$ & 0.215 & 0.209 & 0.217 & 0.220 & 0.006 & 0.99 & 0.42 & 0.48 \\
\hline 139 to $229 \mathrm{~d}$ & 0.115 & 0.123 & 0.116 & 0.126 & 0.004 & 0.20 & 0.17 & 0.12 \\
\hline 1 to $229 \mathrm{~d}$ & 0.175 & 0.174 & 0.175 & 0.181 & 0.004 & 0.80 & 0.38 & 0.81 \\
\hline \multicolumn{9}{|l|}{ Dietary NE (Mcal/kg) } \\
\hline 1 to $139 \mathrm{~d}$ maintenance & 2.17 & 2.12 & 2.19 & 2.20 & 0.04 & 0.96 & 0.36 & 0.31 \\
\hline 1 to $139 \mathrm{~d}$ gain & 1.49 & 1.45 & 1.51 & 1.52 & 0.03 & 0.96 & 0.36 & 0.31 \\
\hline 139 to $229 \mathrm{~d}$ maintenance & 2.06 & 2.10 & 2.02 & 2.12 & 0.04 & 0.75 & 0.66 & 0.15 \\
\hline 130 to $229 \mathrm{~d}$ gain & 1.40 & 1.43 & 1.36 & 1.45 & 0.04 & 0.75 & 0.66 & 0.15 \\
\hline 1 to $229 \mathrm{~d}$ maintenance & 2.10 & 2.09 & 2.10 & 2.15 & 0.04 & 0.82 & 0.40 & 0.86 \\
\hline 1 to 229 d gain & 1.43 & 1.43 & 1.43 & 1.47 & 0.03 & 0.82 & 0.40 & 0.86 \\
\hline
\end{tabular}

SEM, standard error of the mean; ADG, average daily gain; DMI, dry matter intake; NE, net energy.

${ }^{1}$ Initial weight is off-truck arrival weight. Interim and final weights reduced $4 \%$ to account for fill.

final harvest weight, there were no treatment effects ( $>0.10)$ on carcass characteristics (Table 3). Comparable studies involving yeast cell wall are limited. With regard to yeast supplementation, per se, Hinman et al. (1998) and Baumann et al. (2004) did not observe an effect of supplemental yeast on carcass characteristics of feedlot steers. Gomes et al. (2009) observed that supplemental yeast increased carcass dressing percentage, but did was without effect on other carcass measures. Swyers et al. (2014) observed that supplemental yeast increased the proportion of carcass that graded USDA Choice or better.
Experiment 2, influence of enzymatically hydrolyzed yeast on digestive function of steers

Treatment effects on characteristics of digestion are shown in Table 4 . There were no treatment effects $(p>0.10)$ on ruminal digestion of $\mathrm{OM}$, starch, feed-N, microbial efficiency ( $\mathrm{g}$ microbial $\mathrm{N} / \mathrm{kg} \mathrm{OM}$ fermented) and $\mathrm{N}$ efficiency (non-ammonia $\mathrm{N}$ entering the small intestine/ $\mathrm{N}$ intake). Ruminal digestion of NDF tended to increase (linear effect; $p=0.08$ ) with the increasing level of EHY, reflecting a stimulatory effect of EHY on cellulase activity (Kmet et al., 1992). There were no treatment effects ( $p>0.10)$ on total tract digestion of DM, OM, NDF, starch, and N.

Table 3. Influence of enzymatically hydrolyzed yeast (EHY) supplementation on carcass characteristics of feedlot steers

\begin{tabular}{|c|c|c|c|c|c|c|c|c|}
\hline \multirow{2}{*}{ Item } & \multicolumn{4}{|c|}{ EHY (g/steer/d) } & \multirow{2}{*}{ SEM } & \multicolumn{3}{|c|}{ p-value } \\
\hline & 0 & 1 & 2 & 3 & & 0 vs EHY & Linear & Quadratic \\
\hline Pen replications & 5 & 5 & 5 & 5 & & & & \\
\hline $\mathrm{HCW}$ & 357.9 & 356.4 & 353.3 & 364.3 & 6.6 & 0.99 & 0.60 & 0.60 \\
\hline Dressing percentage & 65.0 & 65.4 & 64.4 & 64.4 & 0.6 & 0.65 & 0.29 & 0.43 \\
\hline Fat thickness $(\mathrm{cm})$ & 1.46 & 1.37 & 1.33 & 1.24 & 0.13 & 0.35 & 0.25 & 0.85 \\
\hline KPH (\%) & 2.56 & 2.71 & 2.86 & 2.58 & 0.07 & 0.11 & 0.55 & 0.24 \\
\hline $\mathrm{LM}$ area $\left(\mathrm{cm}^{2}\right)$ & 85.4 & 84.3 & 81.4 & 80.9 & 2.9 & 0.64 & 0.23 & 0.93 \\
\hline Yield grade (\%) & 49.3 & 49.3 & 49.1 & 49.2 & 0.4 & 0.82 & 0.70 & 0.76 \\
\hline
\end{tabular}

SEM, standard error of the mean; HCW, hot carcass weights; KPH, kidney, pelvic and heart fat, as a percentage of HCW; LM, Longissimus muscle. 
Table 4. Influence of enzymatically hydrolyzed yeast (EHY) supplementation on characteristics of ruminal and total tract digestion

\begin{tabular}{|c|c|c|c|c|c|c|c|c|}
\hline \multirow{2}{*}{ Item } & \multicolumn{4}{|c|}{ EHY (g/steer/d) } & \multirow{2}{*}{ SEM } & \multicolumn{3}{|c|}{$\mathrm{p}$ value } \\
\hline & 0 & 1 & 2 & 3 & & 0 vs EHY & Linear & Quadratic \\
\hline \multicolumn{9}{|l|}{ Intake $(\mathrm{g} / \mathrm{d})^{1}$} \\
\hline Dry matter & 6,015 & 6,016 & 6,017 & 6,018 & & & & \\
\hline Organic matter & 5,637 & 5,638 & 5,639 & 5,640 & & & & \\
\hline NDF & 1,227 & 1,227 & 1,228 & 1,228 & & & & \\
\hline Starch & 2,937 & 2,938 & 2,938 & 2,939 & & & & \\
\hline Nitrogen & 136 & 136 & 136 & 136 & & & & \\
\hline \multicolumn{9}{|l|}{ Flow to duodenum (g/d) } \\
\hline Organic matter & 2,874 & 2,894 & 2,981 & 2,901 & 75 & 0.58 & 0.63 & 0.53 \\
\hline $\mathrm{NDF}$ & 724 & 718 & 661 & 665 & 25 & 0.18 & 0.08 & 0.86 \\
\hline Starch & 343 & 323 & 387 & 376 & 41 & 0.70 & 0.41 & 0.92 \\
\hline Nitrogen & 147 & 145 & 157 & 144 & 4.9 & 0.80 & 0.89 & 0.32 \\
\hline Microbial N & 89.2 & 84.8 & 91.9 & 86.8 & 2.6 & 0.67 & 0.99 & 0.90 \\
\hline Ammonia N & 6.47 & 5.61 & 6.09 & 6.07 & 0.4 & 0.24 & 0.67 & 0.29 \\
\hline Non ammonia $\mathrm{N}$ & 140 & 139 & 150 & 138 & 4.9 & 0.72 & 0.87 & 0.29 \\
\hline Feed N & 51.2 & 54.3 & 58.7 & 50.9 & 3.8 & 0.47 & 0.84 & 0.20 \\
\hline \multicolumn{9}{|l|}{ Ruminal digestion (\%) } \\
\hline Organic matter & 64.83 & 63.71 & 63.43 & 63.96 & 1.34 & 0.49 & 0.65 & 0.56 \\
\hline NDF & 41.00 & 41.48 & 46.13 & 45.87 & 2.01 & 0.18 & 0.08 & 0.86 \\
\hline Starch & 88.32 & 89.00 & 86.82 & 87.22 & 1.39 & 0.70 & 0.41 & 0.92 \\
\hline Feed N & 62.29 & 60.04 & 56.79 & 62.52 & 2.80 & 0.49 & 0.84 & 0.20 \\
\hline Microbial efficiency $^{2}$ & 24.43 & 23.65 & 25.81 & 24.14 & 0.76 & 0.91 & 0.71 & 0.58 \\
\hline $\mathrm{N}$ efficiency ${ }^{3}$ & 1.03 & 1.02 & 1.11 & 1.01 & 0.04 & 0.73 & 0.88 & 0.29 \\
\hline \multicolumn{9}{|l|}{ Fecal excretion $(\mathrm{g} / \mathrm{d})$} \\
\hline Dry matter & 1,285 & 1,205 & 1,308 & 1,200 & 36 & 0.30 & 0.38 & 0.71 \\
\hline Organic matter & 1,117 & 1,043 & 1,143 & 1,033 & 66 & 0.29 & 0.34 & 0.61 \\
\hline NDF & 630 & 615 & 654 & 549 & 28 & 0.49 & 0.16 & 0.16 \\
\hline Starch & 20.2 & 16.9 & 23.1 & 16.2 & 2.8 & 0.66 & 0.66 & 0.56 \\
\hline Nitrogen & 33.2 & 30.7 & 34.2 & 31.9 & 1.1 & 0.50 & 0.97 & 0.93 \\
\hline \multicolumn{9}{|l|}{ Total tract digestion $(\%)$} \\
\hline Dry matter & 78.64 & 79.98 & 78.26 & 80.06 & 0.60 & 0.30 & 0.38 & 0.71 \\
\hline Organic matter & 80.18 & 81.50 & 79.73 & 81.68 & 0.58 & 0.28 & 0.33 & 0.61 \\
\hline NDF & 48.66 & 49.91 & 46.75 & 55.26 & 2.30 & 0.49 & 0.16 & 0.16 \\
\hline Starch & 99.31 & 99.43 & 99.21 & 99.45 & 0.10 & 0.99 & 0.68 & 0.59 \\
\hline Nitrogen & 75.58 & 77.41 & 74.81 & 76.51 & 0.79 & 0.76 & 0.96 & 0.93 \\
\hline
\end{tabular}

SEM, standard error of mean; NDF, neutral detergent fiber.

${ }^{1}$ Dry matter intake was restricted to $2.2 \%$ of body weight.

${ }^{2}$ Microbial nitrogen, $\mathrm{g} / \mathrm{kg}$ organic matter fermented.

${ }^{3}$ Non-ammonia nitrogen flow to the small intestine as a fraction of nitrogen intake.

Comparable studies evaluating effects of supplemental EHY on characteristics of digestion are limited. Lei et al. (2013) observed increased fiber digestion in steers supplemented with yeast cell walls. Indeed, enhanced fiber digestion has been a consistent response to yeast supplementation, per se, across a variety of diets and feeding practices (Dawson et al., 1990; Williams et al., 1991; Zinn and Borquez, 1993; Plata et al., 1994; LópezSoto et al., 2013). Nevertheless, as fiber comprises a comparatively small component of the conventional finishing diets, effects of supplementation on total tract digestion were small and non-appreciable.
Treatment effects on characteristics of ruminal fermentation are shown in Table 5. There were no treatment effects $(\mathrm{p}>0.10)$ on ruminal $\mathrm{pH}$, total VFA, or molar proportion of butyrate. Consistent with the present study, Baumann et al. (2004) and Lopez-Soto et al. (2013) did not observe an effect of supplemental yeast on ruminal $\mathrm{pH}$. In contrast, Vyas et al. (2014) observed an increase in ruminal $\mathrm{pH}$ with yeast supplementation of feedlot diet. Although, as in the present study, yeast supplementation did not affect ruminal VFA concentration.

Supplemental EHY decreased ruminal molar proportion of acetate $(\mathrm{p}=0.08)$, increased molar proportion of 
Table 5. Influence of enzymatically hydrolyzed yeast (EHY) supplementation on characteristics of ruminal fermentation

\begin{tabular}{|c|c|c|c|c|c|c|c|c|}
\hline \multirow{2}{*}{ Item } & \multicolumn{4}{|c|}{ EHY (g/steer/d) } & \multirow{2}{*}{ SEM } & \multicolumn{3}{|c|}{$\mathrm{p}$ value } \\
\hline & 0 & 1 & 2 & 3 & & 0 vs EHY & Linear & Quadratic \\
\hline Ruminal pH & 5.93 & 5.95 & 6.11 & 5.80 & 0.10 & 0.87 & 0.61 & 0.16 \\
\hline Total VFA & 101.6 & 99.5 & 88.9 & 94.3 & 7.2 & 0.42 & 0.36 & 0.63 \\
\hline \multicolumn{9}{|c|}{ Ruminal VFA (mol/100 mol) } \\
\hline Acetate & 61.6 & 56.3 & 54.8 & 58.1 & 2.1 & 0.08 & 0.25 & 0.09 \\
\hline Propionate & 26.9 & 34.4 & 35.9 & 33.4 & 3.2 & 0.09 & 0.20 & 0.17 \\
\hline Butyrate & 11.5 & 9.3 & 9.3 & 8.5 & 1.3 & 0.16 & 0.19 & 0.62 \\
\hline Acetate/propionate & 2.46 & 1.68 & 1.54 & 1.81 & 0.31 & 0.07 & 0.18 & 0.14 \\
\hline Methane $^{1}$ & 0.53 & 0.44 & 0.42 & 0.46 & 0.04 & 0.09 & 0.22 & 0.15 \\
\hline
\end{tabular}

SEM, standard error of mean; VFA, volatile fatty acids.

${ }^{1}$ Methane, $\mathrm{mol} / \mathrm{mol}$ glucose equivalent fermented.

propionate $(\mathrm{p}=0.09)$, and decreased acetate:propionate molar ratio $(\mathrm{p}=0.07)$ and estimated ruminal methane production $(\mathrm{p}=0.09)$. A similar effect on ruminal acetate:propionate supplementation has been observed with yeast supplementation, per se (Williams et al., 1991; Plata et al., 1994; Hinman et al., 1998).

\section{CONCLUSION}

Supplemental EHY may enhance DMI and ADG of feedlot steers during periods of high ambient temperature. Supplemental EHY may also enhance ruminal fiber digestion and decrease ruminal acetate:propionate molar ratios in feedlot steers fed steam-flaked corn-based finishing diets.

\section{REFERENCES}

AOAC. 1986. Official Methods of Analysis, 13th ed. Association of Official Analytical Chemists, Washington, DC, USA.

AOAC. 2000. Official Methods of Analysis, 17th ed. Association of Official Analytical Chemists, Washington, DC, USA.

Baumann, T. A., A. E. Radunz, G. P. Lardy, V. L. Andersons, J. S. Caton, and M. L. Bauer. 2004. Effects of tempering and a yeast-enzyme mixture on intake, ruminal fermentation, in situ disappearance, performance, and carcass traits in steers fed barley-based diets. Prof. Anim. Sci. 20:178-184.

Beauchemin, K. A., W. Z. Yang, D. P. Morgavi, G. R. Ghorbani, W. Kautz, and J. A. Z. Leedle. 2003. Effects of bacterial direct-fed microbials and yeast on site and extent of digestion, blood chemistry, and subclinical ruminal acidosis in feedlot cattle. J. Anim. Sci. 81:1628-1640.

Bergen, W. G., D. B. Purser, and J. H. Cline. 1968. Effect of ration on the nutritive quality of rumen microbial protein. J. Anim. Sci. 27:1497-1501.

Blackshaw, J. K. and A. W. Blackshaw. 1994. Heat stress in cattle and the effect of shade on production and behaviour: A review. Aust. J. Exp. Agric. 34:285-295.

Chae, B. J., J. D. Lohakare, W. K. Moon, S. L. Lee, Y. H. Park, and T. W. Hahn. 2006. Effects of supplementation of betaglucan on the growth performance and immunity in broilers. Res. Vet. Sci. 80:291-298.
Dawson, K. A., K. E. Newman, and J. A. Boling. 1990. Effects of microbial supplements containing yeast and lactobacilli on roughage-fed ruminal microbial activities. J. Anim. Sci. 68:3392-3398.

Finck, D., S. Parr, T. R. Young, J. A. Carroll, J. Corley, A. Estefan, and B. Johnson. 2010. Interactive effects of yeast and yeast cell wall material on feedlot performance during the receiving period of stressed beef cattle. J. Anim. Sci. 88(E-Supplement 2):383 (abstract).

Ganner, A., C. Stoiber, D. Wieder, and G. Schatzmayr. 2010. Quantitative in vitro assay to evaluate the capability of yeast cell wall fractions from Trichosporon mycotoxinivorans to selectively bind gram negative pathogens. J. Microbiol. Methods 83:168-174.

Gomes, R. C., P. R. Leme, S. L. Silva, M. T. Antunes, and C. F. Guedes. 2009. Carcass quality of feedlot finished steers fed yeast, monensin, and the association of both additives. Arq. Bras. Med. Vet. Zootec. 61:648-654.

Hill, F. N. and D. L. Anderson. 1958. Comparison of metabolizable energy and productive energy determinations with growing chicks. J. Nutr. 64:587-603.

Hinman, D. D., S. J. Sorensen, and P. A. Momont. 1998. Effect of yeast culture on steer performance, apparent diet digestibility, and carcass measurements when used in a barley and potato finishing diet. Prof. Anim. Sci. 14:173-177.

Hubbard, K. G., D. E. Stookesbury, G. L. Hahn, and T. L. Mader. 1999. A climatological perspective on feedlot cattle performance and mortality to the Temperature-Humidity index. J. Prod. Agric. 12:650-653.

Kmet, V., Z. Jonecova, and M. Stachova. 1992. The effect of pectynolitic yeasts on rumen microflora. J. Anim. Feed Sci. $1: 165-170$

Lei, C. L., G. Z. Dong, L. Jin, S. Zhang, and J. Zhou. 2013. Effects of dietary supplementation of montmorillonite and yeast cell wall on lipopolysaccharide adsorption, nutrient digestibility and growth performance in beef cattle. Livest. Sci. 158:57-63.

Li, J., D. F. Li, J. J. Xing, Z. B. Cheng, and C. H. Lai. 2006. Effects of beta-glucan extracted from Saccharomyces cerevisiae on growth performance, and immunological and somatotropic responses of pigs challenged with Escherichia coli lipopolysaccharide. J. Anim. Sci. 84:2374-2381.

Liu, J., G. Ye, Y. Zhou, Y. Liu, L. Zhao, Y. Liu, X. Chen, D. Huang, S. F. Liao, and K. Huang. 2014. Feeding glycerol-enriched yeast culture improves performance, energy status, and heat 
shock protein gene expression of lactating Holstein cows under heat stress. J. Anim. Sci. 92:2494-2502.

López-Soto, M. A., Y. S. Valdés-García, A. Plascencia, A. Barreras, B. I. Castro-Perez, A. Estrada-Angulo, F. G. Ríos, A. GómezVazquez, L. Corona, and R. A. Zinn. 2013. Influence of feeding live yeast on microbial protein synthesis and nutrient digestibility in steers fed a steam-flaked corn-based diet. Acta Agric. Scand., Section A - Anim. Sci. 63:39-46.

Lowry, V. K., M. B. Farnell, P. J. Ferro, C. L. Swaggerty, A. Bahl, and M. H. Kogut. 2005. Purified beta-glucan as an abiotic feed additive up-regulates the innate immune response in immature chickens against Salmonella enterica serovar Enteritidis. Int. J. Food Microbiol. 98:309-318.

Mader, T. L., M. S. Davis, and T. Brown-Brandl. 2006. Environmental factors influencing heat stress in feedlot cattle. J. Anim. Sci. 84:712-719.

Murphey, C. E., D. K. Hallett, W. E. Tyler, and J. C. Pierce Jr. 1960. Estimating yields of retail cuts from beef carcasses. Paper presented at the 62nd meeting of the American Society of Animal Production, Chicago, IL, USA.

Nocek, J. E., M. G. Holt, and J. Oppy. 2011. Effects of supplementation with yeast culture and enzymatically hydrolyzed yeast on performance of early lactation dairy cattle. J. Dairy Sci. 94:4046-4056.

NRC. 1984. Nutrient Requirements of Beef Cattle, 6th rev. ed. National Academy Press, Washington, DC, USA.

NRC. 1996. Nutrient Requirements of Beef Cattle, 7th rev. ed. National Academy Press, Washington, DC, USA.

Ørskov, E. R., N. A. MacLeod, and D. J. Kyle. 1986. Flow of nitrogen from the rumen and abomasum in cattle and sheep given protein-free nutrients by intragastric infusion. Br. J. Nutr. 56:241-248.

Plata, P. F., M. Mendoza, J. R. Barcena-Gama, and M. S. Gonzalez. 1994. Effect of a yeast culture (Saccharomyces cerevisiae) on neutral detergent fiber digestion in steers fed oat straw based diets. Anim. Feed Sci. Technol. 49:203-210.

Reisinger, N., A. Gannera, S. Masching, G. Schatzmayr, and T. J. Applegate. 2012. Efficacy of a yeast derivative on broiler performance, intestinal morphology and blood profile. Livest. Sci. 143:195-200.

Rhoads, M. L., R. P. Rhoads, M. J. VanBaale, R. J. Collier, S. R. Sanders, W. J. Weber, B. A. Crooker, and L. H. Baumgard. 2009. Effects of heat stress and plane of nutrition on lactating Holstein cows: I. Production, metabolism, and aspects of circulating somatotropin. J. Dairy Sci. 92:1986-1997.

Sanchez, N. C. B., T. R. Young, J. A. Carroll, J. R. Corley, R. J. Rathmann, and B. J. Johnson. 2013. Yeast cell wall supplementation alters aspects of the physiological and acute phase responses of crossbred heifers to an endotoxin challenge. Innate Immun. 19:411-419.
Sanchez, N. C. B., T. R. Young, J. A. Carroll, J. R. Corley, R. J. Rathmann, and B. J. Johnson. 2014. Yeast cell wall supplementation alters the metabolic responses of crossbred heifers to an endotoxin challenge. Innate Immun. 20:104-112.

Swyers, K. L., J. J. Wagner, K. L. Dorton, and S. L. Archibeque. 2014. Evaluation of Saccharomyces cerevisiae fermentation product as an alternative to monensin on growth performance, cost of gain, and carcass characteristics of heavy-weight yearling beef steers. J. Anim. Sci. 92:2538-2545.

USDA. 1997. United States Standards for Grading of Carcass Beef. Washington (DC): Agricultural Marketing Service, USDA.

Van Soest, P. J., J. B. Robertson, and B. A. Lewis. 1991. Methods for dietary fiber, neutral detergent fiber, and nonstarch polysaccharides in relation to animal nutrition. J. Dairy Sci. 74:3583-3597.

Vyas, D., A. Uwizeye, R. Mohammed, W. Z. Yang, N. D. Walker, and K. A. Beauchemin. 2014. The effects of active dried and killed dried yeast on subacute ruminal acidosis, ruminal fermentation, and nutrient digestibility in beef heifers. J. Anim. Sci. 92:724-732.

Williams, P. E.V., C. A. G. Tait, G. M. Innes, and C. J. Newbold. 1991. Effects of the inclusion of yeast culture (Saccharomyces cerevisiae plus growth medium) in the diet of dairy cows on milk yield and forage degradation and fermentation patterns in the rumen of steers. J. Anim. Sci. 69:3016-3026.

Wolin, M. J. 1960. A theoretical rumen fermentation balance. J. Dairy Sci. 43:1452-1459.

Young, B. A. and A. B. Hall. 1993. Heat load in cattle in the Australian environment. In: Australian Beef (Ed. B. Coombs). Morescope Pty Ltd., Melbourne, Victoria, Australia. pp. 143148

Zinn, R. A. 1988. Comparative feeding value of supplemental fat in finishing diets for feedlot steers supplemented with and without monensin. J. Anim. Sci. 66:213-227.

Zinn, R. A. 1990. Influence of flake density on the comparative feeding value of steam-flaked corn for feedlot cattle. J. Anim. Sci. 68:767-775.

Zinn, R. A. and F. N. Owens. 1986. A rapid procedure for purine measurement and its use for estimating net ruminal protein synthesis. Can. J. Anim. Sci. 66:157-166.

Zinn, R. A. and A. Plascencia. 1993. Interaction of whole cottonseed and supplemental fat on digestive function in cattle. J. Anim. Sci. 71:11-17.

Zinn, R. A. and J. L. Borquez. 1993. Interaction of restricted versus ad libitum access to feed on effects of yeast culture supplementation on digestive function in feedlot calves. Western Sec. Am. Soc. Anim. Sci. 44:424.

Zinn, R. A. and Y. Shen. 1998. An evaluation of ruminally degradable intake protein and metabolizable amino acid requirements of feedlot calves. J. Anim. Sci. 76:1280-1289. 